\title{
INTERNATIONALIZATION OF SMALL AND MEDIUM-SIZED ENTERPRISES FROM CENTRAL AND EASTERN EUROPE: A THEORETICAL FRAMEWORK
}

\author{
Sonia Ferencikova \\ School of Management, Bratislava, Slovakia
}

\begin{abstract}
The research objective of this paper is to study three main internationalization theories in order to formulate the implications of them for Central and Eastern European companies and to test their applicability on internationalization patterns of the local SMEs. The article summarizes three firmlevel internationalization theories relevant to CEE companies: Uppsala model, network view and international new venture approach. Typically, the classical international theories are based on the internationalization patterns of firms from developed economies. In the search for potential divergence, each chosen theory is followed by its potential implications for CEE firms as there could be differences given the nature of the origin of the companies coming from transitional, mostly small economies with low resources and negative made-in effect.
\end{abstract}

Keywords: internationalization, small and medium-sized enterprises, SMEs, CEE.

DOI: http://dx.doi.org/10.15549/jeecar.v5i2.225

\section{PROBLEM DEFINITION AND RESEARCH OBJECTIVE}

The article summarizes three major firm-level internationalization theories and points out their main research findings. Typically, the commonly cited theories are based on the internationalization patterns of firms emerging from advanced economies, like the US or Western Europe. With this respect and in the search for potential differences, each major internationalization theory is followed by its potential implications for CEE firms. A few selected internationalization studies with a CEE focus are analyzed as well. In some cases, their authors must develop completely new research perspectives to explain the very specific local environments. The research objective of this paper is to study three chosen internationalization theories in order to test the applicability on internationalization patterns of CEE firms, as there could be differences given the nature of the origin of the companies coming from former, mostly small transitional economies with low resources and negative made-in effect. CEE region was chosen as a platform for this analysis due to its relatively short and turbulent story of the creation of market economy, originally on the fundamentals of the problematic socialist economy, and due to its differences to the developed countries based on the history of dramatic, fast, and deep changes in the society and economy, and lack of appropriate resources.

\section{ANALYSIS OF THE MAIN THEORIES AND IMPLICATIONS FOR CEE}

\section{Uppsala model}

This model describes firm-level internationalization as a process of incremental adjustments to changing environments, driven by experiential knowledge and learning (Johanson \& Vahlne, 1977). Johanson and Vahlne believe that internationalization should 
occur in multiple stages in order to successfully increase firms' commitments in foreign markets. The model considers two aspects to explain the internationalization process of firms: state and change aspects. While state aspects are represented by the market knowledge and market commitment of resources to foreign markets, change aspects are focused on the decisions to commit resources and the performance of business activities (Johanson \& Vahlne, 1977). This model actually deals with the gradual increase of the knowledge, international involvement and activity (what seems to be very similar to the situation of the CEE companies in the transition process to market economies one-two decades later).

Due to the recent changes in business environments and theoretical advances, the Uppsala model was revised in 2009: firstly, it claims that firms operate in markets defined by networks of relationships, rather than being parts of independent webs of suppliers and customers (Johanson \& Vahlne, 2009). With this respect, "insidership" in close networks is necessary for firm's successful internationalization, while "outsidership" from such networks represents a significant obstacle in the process. Outsidership from a particular network can additionally cause a greater uncertainty than the psychic distance alone (Cassia \& Baronchelli, 2008). Secondly, such networks of relationships foster knowledge creation, trust and commitment building for firms. Johanson and Vahlne (2009) therefore, emphasize the importance of networks as the key influencing factor for the firm-level internationalization.

The revised model puts more emphasis on opportunities. They are assumed to be the most important element linked to knowledge that drives the process of internationalization (Johanson \& Vahlne, 2009). The authors also believe that the business network concept along with great opportunities can explain why some firms deviate from the originally proposed establishment chain and why some firms, mainly small new ventures, internationalize very rapidly (Johanson \& Vahlne, 2009).

\section{Implications on CEE countries}

The beginning of the 90s meant several unexpected challenges for local CEE firms. Lack of foreign-market knowledge, know-how in operations, and inadequate foreign language capabilities forced local firms to concentrate their foreign activities on neighboring countries, primarily. The political history of the CEE region supports the idea of psychic distance as well.. After all, close historical ties, cultural, language and economic similarities of the countries must not be neglected. Aside from the aspect of psychic distance, the pattern of the establishment chain of the Uppsala model was typically used by the local firms; which entered neighboring markets first, established manufacturing facilities later and eventually, started manufacturing products and services abroad (Ferencikova \& Schuh, 2012).

Multiple studies on firm-level internationalization with the focus on the CEE region confirm the patterns of the establishment chain and psychic distance. Jaklič and Svetličič (2003) examine growth of multinational firms from Czech Republic, Estonia, Hungary, Poland and Slovenia. The main findings show that firms internationalize primarily to neighboring countries, which can be explained by the aspect of psychic distance and historical ties, although some globally active firms were identified as well (Jaklič \& Svetličič, 2003). Additionally, the study underlines the significance of both firms' past experience and ambitious plans, as they experienced positive effects from the outward foreign direct investment.

Mockaitis, Vaiginiene, \& Giedraitis (2006) examine the internationalization patterns of Lithuanian manufacturing firms. They state that the degree of internationalization is positively related to a firm's age and size. Unlike small firms which tend to depend on intermediaries, large firms typically have more resources to seek potential foreign partners. Additionally, young firms usually suffer from insufficient experience, network connections, and knowledge, which relates to the Uppsala model and the incremental process of internationallization, gradual knowledge, and experience acquisition. This study concludes, that the observed firms operate in an uncertain environment without proactively seeking for opportunities and therefore, no clear patterns to describe the process of internationalization are found (Mockaitis, Vaiginiene, \& Giedraitis, 2006).

Vissak, Ibeh \& Paliwoda (2007) examine the internationalization processes of four Baltic firms established during 1993-1999. One of the aims of this qualitative analysis is to test the 
applicability of the major internationalization theories on selected firms. The findings support the significance of the resource-based view when analyzing the firm-level internationalization process; yet still incorporate the significance of the Uppsala model perspectives. This study supports the two conclusions: All examined firms support the aspect of psychic distance by focusing on the neighboring markets first, as well as the establishment of a chain pattern by supporting the importance of the lower commitment mode of internationalization at a firm's early stages of the process (Vissak, Ibeh, \& Paliwoda, 2007).

Stoian, Rialp, Rialp and Jarvis investigate the internationalization of small firms from CEE: their research supports the applicability of the revised Uppsala internationalization process model, which highlights the key role of networks for international activity. The revisited Uppsala model proves to be generally valid for the small firms analyzed in this study. Networks play a crucial role for knowledge creation and exchange, and frequently represent the most reliable resource at firms' disposal (Stoian et al., 2016).

Based on the empirical evidence on firm-level internationalization of CEE countries, the Uppsala model seem to be relevant for many privatized firms, SMEs, and start-ups in classical industries (agriculture, FMCG, especially food products, construction etc.). However, it is hardly applicable for start-ups in the ICT sector (Ferencikova \& Hluskova, 2015).

\section{Network view}

This view is a theory stream discussing the importance of business networks for firm-level internationalization (Johanson \& Vahlne, 2009). Business networks represent sets of interlinked relationships between two or more actors who control business activities and resources (Forsgren \& Johanson, 1992), and include individual firms, customers, suppliers, agents, competitors, and occasionally governments and universities (Chetty S., 1994). Multiple studies analyze how firms use their relationships within networks to improve their performance by sharing knowledge and skills with the other actors (Chetty \& Blankenburg Holm, 2000). Acording to Johanson and Vahlne (2009), being part of business networks is necessary for a firm's successful internationalization, while being an outsider represents a significant obstacle. Similarly to the Uppsala model, the network view believes that firms can gain relevant knowledge about a specific market (network) only when being a part if it (Forsgren \& Johanson, 1992).

Swedish firms and their strong industrial structure represent a great example to show the importance of long-lasting network relationships (Andersson, 2002). The Swedish economy is composed of multiple large firms and many small firms. Typically, the smaller firms are suppliers to these strong and large players, which are highly internationalized. Being a supplier to such big players enables smaller firms to access their networks, build relationships, trust, commitment and share knowledge and experience easily. (Andersson, 2002). However, being part of a business network represents challenges as well. Each activity within a network is, to a certain degree, dependent on the performance of other actors and their focus. Differences in hierarchical levels or functional roles among the firms can significantly influence the pursued business strategies within the network. In extreme cases, the strongest players focus mainly on promoting their own interests (Forsgren \& Johanson, 1992). Nonetheless, the network view believes that cooperation is more efficient than competition for the development of any firm (Andersson, 2002). Such cooperation is beneficial, as it creates highly competitive firms.

\section{Implications on CEE countries}

Business networks represent many advantages for local CEE firms. Firstly, similarly to other firms, CEE firms enjoy favorable factor conditions for their internationalization, including specialized knowledge, know-how, experience sharing, and access to resources. Secondly, and especially after the fall of communism, firms were experiencing difficulties in securing the financing. As a result, many firms tried to enter various networks or business associations in order to secure bank financing (Oluwarotimi \& Sarmistha, 2013). Additionally, the internationalization process of state owned firms or IT start-ups can be fostered by network relationships and support from the government, specialized knowledge and also by chance (Ferencikova \& Schuh, 2012). The development of manufacturing facilities and MNCs becoming active in the CEE region enabled smaller local firms to access important 
industry-related networks of big international corporations.

Multiple studies on firm-level internationallization with a focus on the CEE region confirm the significance of the business networks: one of the first studies supporting the view that entering business network of MNCs is important for the survival of the local CEE companies, is the study of Ferencikova (2001). She argues that local joint ventures created with the foreign MNCs helped them to survive the transformation crisis through offering them entry into their distribution networks. The creation of local joint ventures with the foreign partners proved to be vital for some CEE parent companies as well, as they survived the crisis by becoming the supplier of their own joint venture, thus the supplier of the Western parent company.

Mroczkowski, Carmel and Saleh (2003) also show the relevance of business networks and partnerships. Their study focuses on the IT exporting firms from Bulgaria, Czech Republic, Hungary, Poland and Romania, which compete for outsourcing work in Western Europe and the USA. The authors believe that forming strategic partnerships with Western firms is the fastest way to obtain the necessary experience, management expertise and important contacts to large investors. Partnerships with research institutions and universities represent a great way to obtain young talent, knowledge and information. (Mroczkowski, Carmel, \& Saleh, 2003).

The above-mentioned study of Vissak, Ibeh and Paliwoda (2007), in addition to the other findings, concludes that a firm's relationships and business networks are one of the key internal triggers for firm-level internationallization. The fundamental focus lies within the collaboration among foreign partners, research institutions and universities. Being part of such a network enabled Baltic firms to focus primarily on Western economies rather than the former Soviet countries.

Musteen, Francis and Datta (2010) examine 155 manufacturing Czech SMEs founded after 1989. The objective of the study is to observe the business networks of the firms' CEOs and their influence on the internationalization speed and performance of the firms. The findings show that there is a positive correlation between the common language CEOs share with their international contacts and the speed of internationalization. The authors explain that the dependence on personal ties and business networks is more typical for SMEs than for MNCs. Czech firms after 1989, were experiencing a lack of resources, know-how and knowledge; therefore, international networks represented a great option to solve such challenges and problems. (Musteen, Francis, \& Datta, 2010).

Despite the importance of business networks and relationships for firm-level internationalization, the network view fails to explain why some firms, especially start-ups, internationalize very rapidly even without the necessary network connections at their initial stages. The partial explanation may be found in the fact that the rapid technology advancement has changed the boundaries of the networks, especially in certain industries (Ferencikova \& Hluskova, 2015).

\section{International New Ventures}

International new ventures (INV) theory introduced by Oviatt and McDougall in the early 1990s focuses on rapid internationalization of firms and emphasizes the growing occurrence of firms becoming internationally active already from their inception (Oviatt \& McDougall, 1993). The focus of this concept lies within the firm's age, not the size when examining its ability to internationalize. Oviatt and McDougall (1993) identify four types of INV based on the number of countries involved in the internationalization process, and the coordination of the firm's value chain activities. The global start up, often labeled as born global, is seen as the most radical form of INV, as its operations are geographically unlimited and competitive advantage is achieved by extensive coordination among the firm's business activities. The concept of INV lays special emphasis on the entrepreneurial behavior and its implications to the global start-up creation. The authors believe that such behavior is one of the key reasons to explain the birth of INV. The authors also identify multiple success factors of global startups: a global vision from firm's inception, managers having international experience, global entrepreneurs being well networked abroad, exploiting unique technology or marketing, having non-imitable intangible assets, having closely linked product and service extensions to the firm's unique assets, and having tight coordination of the firm worldwide. The results of this study also confirm the 
importance the entrepreneurial behavior has on the new ventures creation, as the founders of the successful global start-ups were people with superior education, international business experience and well networked abroad (Oviatt \& McDougall, 1995).

Entrepreneurs are believed to have superior market knowledge and thus be aware of resource combinations that could generate profits for firms (Madsen \& Knudsen, 2003). Despite such unique knowledge and business experience, the entrepreneurial decisions are often unplanned, coincidental, and without a prior defined strategic goal. There is a lot of academic discussion related to the categorization of the companies as born global: according to the original authors, a born global firm is a firm that internationalizes within three years after its formation, is less than 20 years old, and generates at least 25 percent of its total output from its activities abroad (Oviatt \& McDougall, 1997). In the newer approaches, speed, commitment level, and commitment pattern of global expansion are typically used criteria (Kuivalainen, Sundqvist, Saarenketo, \& McNaughton, 2012).

The INV literature is connected to the concept of hidden champions as well. According to the definition, a firm must meet the following criteria to be identified as a hidden champion: the firm must be ranked in the top three in the global market or number one on its continent (based on the market share), must generate revenue under $\$ 4$ billion a year and must experience a low level of public awareness (Simon, 1992). Initially it was believed that the hidden champions were formed only in advanced economies, like Germany, Austria and Switzerland. J. Ewing introduced a more comprehensive portrait: he assumes that firms are hidden champions only when they focus on a lucrative but small niche in the market, operate worldwide, aim to be the leader from their inception, avoid commodity products as they are easy to imitate, and constantly innovate and invest in R\&D (Ewing, 2004).

Even though many researchers still try to identify reasons why firms internationalize rapidly and offer better understanding to the dynamics of INV, they all agree that each INV is highly specific, operates under different conditions, and thus, a single generalized explanation for this phenomenon cannot be applied in all cases (Halldin, 2012). In addition, the researchers believe that the role of INV must still be further examined.

\section{Implications on CEE countries}

There are multiple factors that motivate firms from the CEE region to go global right from their inception. Firstly, better opportunities to raise the necessary financial capital abroad rather than in the home country is such an example. In many cases, SMEs from CEE, tend to struggle from insufficient financial support from the local governments. Typically, the less developed countries within the region do not have adequately developed systems yet that would focus on supporting entrepreneurs. Another important factor that motivates local firms to internationalize rapidly is the small customer base in the home countries. Generally, the CEE countries are rather small and thus, offer only limited demand for new ventures. As a result, immediate focus on foreign markets offers not only greater customer base, but also enables firms to generate more sales. Furthermore, both the fear of potential domestic inertia and the recent technological advances support the decision of new ventures to operate globally right from the foundation.

Cieslik and Kaciak (2009) analyze new ventures established in 1993 - 2003 in Poland. The main objective of the study is to examine the internationalization speed of firms in transition economies. The authors identify three types of firms: instant, quick and late exporters. While instant exporters engage in export activities right after their foundation, quick exporters start exporting within the second or third year after their formation and late exporters launch exports in the fourth year or later. Additionally, the authors found out that once the start-up focuses on the domestic market first, it will rarely engage in export activities later. The study also underlines the role of entrepreneurs on the creation of entrepreneurial start-ups (Cieslik \& Kaciak, 2009). Both authors conclude that entrepreneurship and internationalization are closely interlinked concepts and the governments should therefore, focus on educational programs fostering entrepreneurial activities.

Hidden champions from the CEE region are positively associated with a country's economic development. Especially after 2009, politicians and economists emphasized their worries about 
the prosperity of the CEE region, as the SME sector was experiencing difficulties and entrepreneurship was in retreat (Purg \& Rant, 2011).

Rant and Cerne additionally published a study of 112 hidden champions from 18 CEE countries, in which they underline the attitude of the managers as the success factor: they found out that even small firms hold the power of creation and innovation as decisive factors of a successful internationalization. According to them, not only big MNCs. but the small companies and their managers can create novel business landscape via focusing on innovation - by creating something new, not yet seen. On top of that the intentions that the managers bring to the business are more important than the outer realities (Rant \& Cerne, 2017).

Even though various researchers identify reasons why firms internationalize rapidly and offer better understanding to the dynamics of the INV, there is still very limited empirical research conducted with the focus on the CEE region.

\section{KEY FINDINGS, CONCLUSIONS AND FUTURE RESEARCH}

The Uppsala model describes the internationallization process of firms as a result of incremental steps to changing environment driven by the experiential knowledge and learning (Johanson \& Vahlne, 1977). Unlike the original model, the revised model lays more emphasis on business networks to explain the rapid internationalization of some firms (Johanson \& Vahlne, 2009). The network view describes business network as a necessary part for a firm's successful internationalization: the view believes that firms can gain relevant knowledge about a specific network (market) only when being a part of it (Forsgren \& Johanson, 1992). The INV literature introduced by Oviatt \& McDougall focuses on the phenomenon of rapid internationalization of firms. The fundamental focus of this concept lies within the firm's age, not the size when examining its ability to internationalize. Special attention is also paid to the aspect of entrepreneurial behavior and constantly changing international environment, including recent technological advances, increasing mobility of human capital, higher availability of financing options, and a growing number of people with international business experience
(Oviatt \& McDougall, 1993).

Finally, based on this study we can conclude that the theories of internationalization could be modified or enriched. This conclusion is also partially supported by the previous research of the other authors (e.g. Ferencikova jr. 2014, Ferencikova \& Hluskova, 2015).

The author assumes that in case of small, former transitional and relatively well developed countries from CEE region, two paths of internationalization of the local companies are significant: a) SMEs from classical industries prefer neighboring markets (Uppsala theory confirmation). Interestingly enough, the split of the former bigger CEE socialist states like Yugoslavia or Czechoslovakia supports this theory given the tendency of the local companies to do business in their former, known and close environment. b) SMEs from ICT sector internationalize in a very fast way (bornglobal - INV theory confirmation), however they enter very unusual markets, mostly those that are less competitive: Latin America, Africa, and Asia. Due to the severe competition they avoid the most competitive markets, and if they enter them, they need to be a part of the network (network theory confirmation). Given the low availability of the resources plus made-in effect they have very low potential to be hidden champions as defined in the theory.

Based on our study and empirical evidence, we can also state that these are the factors why many SMEs from CEE countries, mostly from non-traditional industries, enter the foreign markets immediately after inception, creating the category of "born-global-squared" companies: technological changes, internet changing all the stages of the value chain, character of their products and services, in many cases small and lower-income domestic markets, internal and external business environment changes - these are the factors that push them immediately on the global markets. This risky "Caesarian section way" internationalization in their cases is also combined with low resources and no experience and therefore leads them to emerging markets and avoidance or later entry to the major and the most competitive markets that are already taken by the competition. As for networking, it may lead to their acquisitions and they are usually trying to avoid it as long as possible. SMEs from traditional industries internationalize in classical Uppsala model way. 
For the future study in the following area we suggest to use more comprehensive qualitative research in order to study the internationalization patterns of local SMEs (motivations, triggers, timing, entry modes, markets, strategies, performance, success and failure stories and lessons learned). Given the characteristics of this research, we assume that case study method could be the optimal one. Quantitative research could be another way to study local SMEs and their internationalization and to test the relevance of the internationalization theories; however there are some limitations that may hinder this, such as difficulties with access to the information needed, reluctance of the companies to share information, methodology changes, limited time periods, language barriers - to name just a few of them. Theoretical scope could be also enlarged in the future studies, for example for eclectic paradigm or resource-based view. In any case, the research opportunities in this area in CEE region are abundant, mostly untapped, and to use them is a very challenging and difficult however rewarding task.

\section{BIBLIOGRAPHY}

Andersson, S. (2002). The Network Perspective Its Origin and Differences to the Marketing Management Approach. Journal of Enterprising Culture, pp. 62-72.

Bals, L., Berry, H., \& Hartmann, E. (2008). What is a "Born global firm?". Philadelphia: Wharton School, University of Pennsylvania.

Barkema, H. G., Kudina, A., \& Yip, G. (2008). Born Global. Business Strategy Review. Winter, pp. 39-44.

Brenčič, M. (2001). Analyzing Competitive Advantage on the Basis of Resource-based View: The Concept of Price and Non-price Factors. Journal for East European Management Studies, pp. 113-130.

Carlson, S. (1966). International Business Research. Uppsala: Acta Universitatis Upsaliensis.

Cassia, F., \& Baronchelli, G. (2008). Internationalization of the firm: stage approach bs. global approach. 8th Global Conference on Business \& Economics. Florence.

Cieslik, J., \& Kaciak, E. (2009). The Speed of Internationalization of Entrepreneurial Start-Ups in a Transition Environment.
Journal of Development Entrepreneurship, pp. 375-392.

Ekeledo, I., \& Sivakumar, K. (2004). International market entry mode strategies of manufacturing firms and service firms: A resource-based perspective. International Marketing Review, pp. 68-101.

Ewing, J. (2004). Hidden Champions: The little known European companies that are conquering the world. Business Week, pp. 42-53.

Fahy, J., Hooley, G., Cox, T., Beracs, J., Fontara, K., \& Snoj, B. (2000). The Development and Impact of Marketing Capabilities in Central Europe. Journal of International Business Studies, pp. 63-81.

Ferencikova, S.(1995) Vstup zahraničného kapitálu do Slovenskej ekonomiky (na príklade vybraných joint ventures) Ekonomický časopis, 43, N. 2, pp. 140 - 153

Ferencikova, S. (2001). Foreign Direct Investment as a Factor of Change: The Case of Slovakia. In D. R. Denison, Managing Organizational Change in Transition Economies (pp. 445-482). London: Lawrence Erlbaum Associates, Inc. Publishers.

Ferencikova, S., \& Schuh, A. (2012). The Internationalization of Firms from Central and Eastern Europe - A Discussion of Theoretical Contributions. Proceedings of the 20th Annual Conference on Marketing and Business Strategies for Central \& Eastern Europe (pp. 39-55). Vienna

Ferencikova, S. jr. (2014) Born-globals vs.Borngraduals.Saarbruecken: Lambert.

Ferencikova, S.- Hluskova, T. (2015) Internationalization of Central and Eastern European companies : theory and its implications in the Slovak IT sector Journal of Eastern European Management Studies, pp. 415-434

Forsgren, M., \& Johanson, J. (1992). Managing networks in international business. Amsterdam: Gordon and Breach science publishers.

Franco, C., Rentocchini, F., \& Vittucci Marzetti, G. (2008). Why do firms invest abroad? An analysis of the motives underlying foreign direct investments. Bologna, Italy: University of Bologna.

Gibbert, M. (2006). Generalizing About Uniqueness: An Essay on an Apparent 
Paradox in the Resource-Based View. Journal of Management Inquiry, pp. 124134.

Grant, R. M. (1991). The Resource-based Theory of Competitive Advantage: Implications for Strategy Formulation. California Management Review, pp. 114-135.

Halldin, T. (2012). Born global firms - do they perform differently? Stockholm, Sweden: Centre of Excellence for Science and Innovation Studies (CESIS).

Chetty, S. (1994). Business Networks as a Determinant of Export Performance. Journal of International Marketing, pp. 11-15.

Chetty, S., \& Blankenburg Holm, D. (2000). The Role of Business Networks in the Internationalisation of Manufacturing Firms: A Longitudinal Case Study. Advances in International Marketing, pp. 333-355.

Jaklič, A., \& Svetličič, M. (2003). The outward Direct Investment from CEECs: Can their Firms compete in the Global Market? Journal of East European Management Studies, pp. 67-83.

Johanson, J., \& Vahlne, J. (2009). The Uppsala Internationalization Process Model Revisited: From Liability of Foreigness to Liability of Outsidership . Journal of International Business Studies, pp. 14111431.

Johanson, J., \& Vahlne, J. E. (1977). The Internationalization Process of the Firm - A Model of Knowledge Development and Increasing Foreign Market Commitments. Journal of International Business Studies, pp. 23-32.

Kuivalainen, O., Sundqvist, S., Saarenketo, S., \& McNaughton, R. (2012). Internationalization patterns of small and medium-sized enterprises. International Marketing Review, pp. 448 - 465.

Madsen, T. K., \& Knudsen, T. (2003). International New Ventures: A New Organizational Form? The Sixth McGill Conference on International Entrepreneurship: Crossing Boundaries and Researching New Frontiers. Odense: University of Ulster.

Mockaitis, A. I., Vaiginiene, E., \& Giedraitis, V. (2006). The Internationalization Efforts of Lithuanian Manufacturing Firms - Strategy or Luck? Research in International Business and Finance, pp. 111-123.
Mroczkowski, T., Carmel, E., \& Saleh, N. (2003). The competitiveness of Central European IT exporters: Can this sector attract Western investment? Journal for East European Management Studies, pp. 173-193.

Musteen, M., Francis, J., \& Datta, D. (2010). The influence of international networks on internationalization speed and performance: A study of Czech SMEs. Journal of World Business, pp. 197-205.

Oluwarotimi, O., \& Sarmistha, P. (2013). The Value of Business Networks in Emerging Economies: An Analysis of Firms' External Financing Opportunities. Applied Financial Economics, pp. 415-432.

Oviatt, B. M., \& McDougall, P. P. (1995). Global Start-Ups: Entrepreneurs on a Worldwide Stage [and Executive Commentary]. The Academy of Management Executive, 30-44.

Oviatt, B. M., \& Phillips McDougall, P. (1993). Toward a Theory of International New Ventures. Journal of International Business Studies, pp. 45-64.

Oviatt, B., \& McDougall, P. (1997). Challenges for Internationalization Process Theory: The Case of International New Ventures. Management International Review, pp. 8599.

Purg, D., \& Rant, M. (2011). Hidden Champions in CEE and Dynamically Changing Environments. Bled, Slovenia: CEEMAN.

Rant, M. \& Cerne, S. (2017) How to Successfully Internationalize SMEs from the CEE Region: The Role of Strategies of Differentiation and Education. Journal of Management and Business Administration. Central Europe, pp. 2-27.

Simon, H. (1992). Lessons from Germany's Midsize Giants. Harvard Business Review, pp. 115-123.

Stoian, C. Rialp A., Rialp, J. \& Jarvis, R., (2016) Internationalization of Central and Eastern European small firms: Institutions, resources and networks, Journal of Small Business and Enterprise Development, pp. $105-121$

Vissak, T., Ibeh, K., \& Paliwoda, S. (2007). Internationalising from the European Periphery: Triggers, Processes and Trajectories. Journal of Euromarketing, pp. 35-48. 


\section{ABOUT THE AUTHORS}

Sonia Ferencikova: sferencikova@vsm.sk

Dr. Sonia Ferencikova is the Professor at School of Management Bratislava, Slovakia and holds degrees in international business from the Economic University, Bratislava. She teaches international management at home institution, in addition, she has lectured as Visiting Professor in top universities in the USA, in Australia, France, Austria, Germany, Switzerland, Belgium, Finland, Hungary, Ukraine and Russia. Her research is focused on market entry strategies, investing and doing business in the region. Her numerous publications on these subjects include more than sixty journal articles, case studies and research papers published in Europe and USA as well as ten books and more than twenty coauthored books. 